Ewa Masłowska (1)

Instytut Slawistyki Polskiej Akademii Nauk, Warszawa

ejmaslowska@gmail.com

\title{
ZAPRZEDAĆ DUSZĘ DIABŁU - REPRODUKOWALNOŚĆ MITU WE FRAZEMATYCE $Z$ POLSKIEGO OBSZARU GWAROWEGO I JĘZYKA POTOCZNEGO W KONTEKŚCIE KULTURY TRADYCYJNEJ
}

Słowa klucze: narratywistyka, mit, frazematyka, reprodukowalność, diabeł, dusza Keywords: language narrative, myth, phrasematics, reproducibility, devil, soul

Mity to metafory duchowych możliwości człowieka.

Te same moce, które przenikają nasze życie, przenikają życie wszechświata ${ }^{1}$.

\section{Myślenie mityczne - myślenie symboliczne}

Myślenie mityczne leży u podstaw wszystkich tradycyjnych kultur świata, które w mitologii zawierają swoją opowieść o początkach istnienia. Religioznawcy i badacze mitu zgodnie przyjmują, że mit stanowi archetypowe doświadczenie sacrum i w tym sensie jest niezniszczalny, przybiera coraz to nowszą postać symboliczną lub objawia się w czynnościach noszących znamiona rytuału, które z racji powtarzalności zapewniają mu stałą pozycję w obrębie wyobrażeń przenikania się świata z zaświatami (Campbell 1994: 49; Lurker 1994: 9; Eliade 2000: 477; Szyjewski 2008: 73). 
Mit opiera się na percepcji dostępnej zmysłom, trzyma się doświadczenia, znosząc jednocześnie granicę między rzeczywistością ziemską a pozazmysłową, co stanowi o jego narracyjnej mocy (Szyjewski 2008: 73). Przebieg zdarzeń przedstawiony w micie reprezentuje uniwersalny przyczynowo-skutkowy schemat narracyjny, który zostaje wykorzystany w interpretacjach zachowań ludzkich, opartych na wątkach mitu, wielokrotnie powielanych i modyfikowanych w obrazowaniu symbolicznym. Ustny przekaz stwarza sprzyjające warunki do wielogłosowego dialogu rzeczywistości z mityczną spuścizną, którą zbiorowa pamięć wybiórczo przechowuje i przetwarza (Masłowska 2014: 178-179). Powielanie wzorców jest zjawiskiem o szerokim zasięgu, a ślady archaicznych matryc znaczeniowych przekazywanych $\mathrm{w}$ tradycji oralnej zachowały się przede wszystkim we frazeologii, a przyjmując szerszą perspektywę - we frazematyce (Chlebda 2010, 2020).

\section{Reprodukty mitu}

Frazem (tu rozumiany jako reprodukt mitu) zaprzedać duszę diabłu stanowi punkt wyjścia rozważań nad językowym sposobem przetwarzania i komunikowania doświadczeń natury psychiczno-duchowej, ściśle związanej z kulturą chrześcijańską i sposobem jej adaptacji do ludowego systemu wartości uwarunkowanego stylem życia i stosunkiem do wcześniejszych wyobrażeń wierzeniowych. Podstawę materiałową stanowią frazemy (związki frazeologiczne i paremie) z polskiego obszaru gwarowego oraz języka potocznego, a także motywy folklorystyczne zaczerpnięte $\mathrm{z}$ bajek, legend i opowieści wierzeniowych, nawiązujące do relacji między człowiekiem a diabłem w kwestii duszy. Kontekstowe odniesienia do zwerbalizowanych form kontaktowania się człowieka ze światem nadprzyrodzonym nie tyle stanowią wypełnienie jego konotacyjnego schematu, ile wskazują na szersze zjawisko reprodukowalności ${ }^{2}$ znaczeń zakorzenionych w zbiorowej pamięci, sięgających mitycznych wyobrażeń o istotach demonicznych, które wywarły wpływ na aksjologiczny status duszy oscylujący wokół pojęć kardynalnych dobra i zła, wolności i zniewolenia, życia i śmierci.

2 Nawiązuję tu do koncepcji przedstawionej przez Wojciecha Chlebdę (2020), który wskazuje na szeroki zasięg zjawiska powielania wzorców, obejmujący różne sfery działalności człowieka w całej rozciągłości czasowej, począwszy od epoki przedpiśmiennej po czasy współczesne. Ślady najbardziej archaicznych matryc znaczeniowych przekazywanych w tradycji oralnej zachowały się przede wszystkich we frazeologii. 


\subsection{Założenia metodologiczne}

W analizie posługiwać się będę instrumentarium mieszczącym się w nurcie badań kognitywnych:

1) teorii schematów przedpojęciowych: CENTRUM - PERYFERII, SIŁY, WIĘZI, KONTROLI, RÓWNOWAGI, CZĘŚCI - CA£ośCI oraz SKALI (PLUS - MINUS), które odzwierciedlają doświadczeniowe podstawy konceptualizacji świata oraz antropocentryczny punkt widzenia, wynikający z budowy ciała ludzkiego i jego sensorycznych zdolności (Johnson 1990; Krzeszowski 1994, 1999; Libura 2000);

2) podmiotowej interpretacji rzeczywistości „wpisanej” w strukturę języka (na wszystkich poziomach: leksyki, semantyki, morfologii, tekstu) oraz porządkowania wspólnej dla danej społeczności wiedzy jako językowego obrazu świata (w ujęciu tzw. etnolingwistyki lubelskiej) ${ }^{3}$;

3) teorii schematów narracyjnych (sceny, scenariusza) w zastosowaniu do narracyjności języka jako zdarzeniowego aspektu językowego obrazu świata, ujętego w kategoriach celu, intencji, przyczyny i skutku (Filar 2013);

4) teorii reprodukowalności w zakresie szeroko rozumianej frazematyki (Chlebda 2020).

Przyjęcie koncepcji „narracyjności języka” w opisie małego fragmentu rzeczywistości, jakim jest akt zaprzedawania duszy diabłu, pozwala na przedstawienie go $\mathrm{w}$ formie ustrukturyzowanego obrazu w ramach wielkiej narracji o świecie (opartej na chrześcijańskim światopoglądzie na temat duszy), w którym mieszczą się też narracje małe (odwołujące się do mitów i ludowej demonologii zawartych w stereotypowych motywach tekstowych) oraz mikronarracje, ukryte w leksyce, frazemach, a odzwierciedlające całą gamę interpretacji i ocen odnośnie do realizacji paktu człowieka $\mathrm{z}$ istotą demoniczną.

Wielka narracja, w którą wpisują się relacje człowieka z diabłem (w ujęciu chrześcijańskim), dotyczy wiedzy na temat biblijnego obrazu świata, w którym ścierają się dwie przeciwstawne siły - dobra (uosobione przez Boga - stworzyciela świata) i zła (reprezentowane przez diabła, dążącego do destrukcji bożych planów względem człowieka i świata). Z aksjologicznej perspektywy istotny jest również chrześcijański koncept duszy jako boskiego, nieśmiertelnego pierwiastka w ciele człowieka, który w sposób naturalny powinien ciążyć ku dobru (Bogu), by zapewnić sobie wieczne życie w niebie. Zgodnie z doktryną chrześcijańską dusza - zdolna odróżniać

3 Założenia badawcze dotyczące językowego obrazu świata tzw. szkoły lubelskiej stawiają człowieka (jako podmiot i konceptualizatora) w centrum badań semantycznych, biorąc pod uwagę takie czynniki, jak: typ racjonalności, wiedza o świecie, system wartości, punkt widzenia, perspektywa, które stanowią podstawę rekonstrukcji kultury z pozycji języka (Tokarski 1988: 35-53, 1993: 335-362, 2001: 231-245, 2014: 117-128; Bartmiński, Niebrzegowska 1998: 211-224; Bartmiński, Niebrzegowska-Bartmińska 2004: 321-358; Bartmiński 2006: 106-130, 2014: 99-115; Niebrzegowska-Bartmińska 2020: 34-39, 115-121). 
dobro od zła - służy człowiekowi za kompas, wskazując drogę do zbawienia. Jednakże człowiek posiadający wolną wolę ma prawo wyboru między dobrem doczesnym a wiecznym, co otwiera przed szatanem pole do działania. Kuszenie dobrami doczesnymi ma na celu zawładnięcie duszą człowieka, by uczynić ofiarę narzędziem w ręku diabła i zamknąć jej drogę do nieba.

Małe narracje dotyczące sporu Boga $z$ szatanem o rząd dusz czerpią wprawdzie inspiracje $\mathrm{z}$ wielkiej chrześcijańskiej opowieści o świecie, jednakże odbiegają od antropogenezy biblijnej w kwestii udziału diabła w dziele stworzenia. Dualistyczną koncepcję aktu stworzenia poświadczają liczne wersje XIX-wiecznych ludowych mitów kosmogonicznych pochodzących z różnych obszarów Słowiańszczyzny ${ }^{4}$. Starotestamentowa narracja znana z Księgi Rodzaju dotycząca losów pierwszych rodziców - stworzonych na obraz i podobieństwo Boga, obdarzonych nieśmiertelną duszą i umieszczonych w raju, a wskutek intrygi szatana pozbawionych wszystkich przywilejów i skazanych za karę na trud życia na ziemi - stanowi punkt wyjścia ludowych interpretacji walki szatana z Bogiem o ludzkie dusze i władzę nad światem ${ }^{5}$.

\subsection{Mityczne podstawy reproduktów}

Zgodnie z dualistycznym wzorcem mitu ludowego aktywność diabła ujawnia się u zarania aktu stworzenia człowieka, o czym mówi jedna z jego wersji:

Zlepił Bóg z gliny człowieka, tchnął nań i człowiek zarusał się, ożył. Dyabeł, widząc to wszystko, wybrał chwilę, gdy człowiek spał, tchnął nań - i osiedlił się w człowieku duch zły i człowiek otrzymał skłonność do złego (Tomicki 1976: 87).

Biblijny motyw zrzucenia szatana - zbuntowanego anioła - z nieba na ziemię dał podstawę do rozwinięcia, najważniejszego dla naszych rozważań, ludowego mitu zwanego Cyrografem Adama. Mityczna treść zawarta w apokryfie opowiada o tym, że diabeł - pozbawiony miejsca w niebie - uzurpuje sobie prawo do ziemi, którą zamieszkują i uprawiają pierwsi rodzice, Adam i Ewa. Diabeł, widząc orzącego ziemię Adama, pod groźbą pozbawienia go możliwości korzystania z jej płodów podstępnie

4 Odnoszę się tu do fundamentalnego opracowania słowiańskiego mitu kosmogonicznego autorstwa Ryszarda Tomickiego (1976, 1980), przyjmując za autorem, że przywołane w tym dziele fragmenty mitu początku, pochodzące $z$ różnych obszarów Słowiańszczyzny (głównie wschodniej i południowej), stanowią wspólne dziedzictwo Słowian, zakorzenione w pamięci zbiorowej i zachowane w przekazie ustnym (zwłaszcza w folklorze).

5 Magdalena Zowczak (2000: 9) uważa Księgę Rodzaju za podstawowe odniesienie do analizy wierzeń ludowych oraz interpretacji wątków zaczerpniętych z biblijnego kanonu w kontekście kultury, w jakiej funkcjonują, a rozwijanych w przekazie ustnym, $\mathrm{z}$ uwzględnieniem jej modelu z przełomu XIX i XX w. 
wymusza umowę, w której pierwszy rodzic godzi się oddać we władanie szatana „tego, co ma, a o czym nie wie”, czyli potomka, który pod nieobecność ojca przyszedł na świat (mit ukraiński, Tomicki 1980: 103). Jednakże symboliczna treść mitycznego wątku odnosi się do wszystkich potomków Adama i Ewy, czyli całej ludzkości, którą zawładnąć miałby szatan, o czym dobitnie świadczy wariant mitycznego bogomilskiego wątku apokryfu, poświadczonego z Macedonii:

Po wyjściu z raju Adam martwi się jednak, co będą jedli, i robi Ewie wyrzuty z powodu grzechu. Ona odpowiada: „Orz, kop, mężu, to się wyżywimy”. Kiedy Adam rozpoczyna pracę, Diabeł przegania go, wyjaśniając, że on jest władcą ziemi. „Jeśli jest jakiś sposób, żebym mógł żyć, rzekł Adam zrozpaczony, to co [mam] robić?” Diabeł uspakaja go: „Osiągniesz sam bez trudu swoje życie, a ja ci [je] jeszcze ułatwię, jeśli dasz mi zapis na swój ród, ten co się urodzi: żywi będą twoi, a umarli moi” (ibid.: 102).

W dalszych apokryficznych wersjach podejmujących motyw rzekomej umowy Boga z diabłem o podział władzy nad niebem (należącym do Boga) i ziemią (przynależną diabłu), rozwijanych na bazie nowotestamentowej idei zbawczej ofiary Jezusa Chrystusa, Syn Boży lub Archanioł zdobywają cyrograf (umowę Boga z diabłem) ukryty przez diabła pod wodą (w rzece Jordan, w Morzu Czarnym), uwalniając tym samym ludzkość od panowania diabła (ibid.: 103-104). Te apokryficzne wątki leżą u podstaw narracji związanych z cyrografem, w których diabeł pokusami stara się nakłonić człowieka do zaprzedania mu swej duszy.

Wprawdzie apokryf o Cyrografie Adama - w różnych wersjach - poświadczony jest tylko z terenów Słowiańszczyzny wschodniej i południowej, nie można jednak wykluczyć, że w swoim czasie występował na szerszym obszarze, skoro jego ślady zachowały się w polskiej frazematyce gwarowej i w języku potocznym. Dla tekstów folklorystycznych mit ten stanowił archetypową bazę, która dała podstawy do licznych transformacji.

\section{Rekonstrukcja scenariusza przyczynowo-skutkowego wzorca narracyjnego w mikronarracjach (w reproduktach frazeologicznych)}

Mikro- i małe narracje, odnoszące się do handlu duszą, odwzorowują mityczny schemat: ktoś zaprzedaje diabłu duszę, żeby zyskać x, który zawarty jest implicite lub explicite w ich strukturze znaczeniowej.

Semantyczne jądro reproduktów, w których ujawnia się waloryzacja zarówno samego czynu, jak i duszy, wynika ze znaczenia leksemu zaprzedać oraz negatywnych konotacji wskazujących na działanie nieetyczne, polegające na poświęceniu wyższych wartości w imię niskich pobudek (zaprzedać ojczyznę wrogowi, zaprzedać dzieci w niewolę). Czasownik ten ma ograniczoną i ustabilizowaną łączliwość leksykalną, występuje często z zaimkiem zwrotnym się, który wnosi asocjacje związane 
z wyrzeczeniem się prawa do wolności, a tym samym przyjęciem postawy służebnej (zaprzedać się obcemu, zaprzedać się władzy) w zamian za inne korzyści.

Scena transakcji między podmiotem a diabłem zawarta we frazie zaprzedać $d u$ szę diabłu wpisuje się w mit cyrografu, ale mikronarracja zawiera jedynie znikome elementy scenariusza, gdyż wymienia tylko jednego uczestnika aktu - diabła w roli kupującego, podczas gdy sprzedawca występuje w presupozycji. Wprawdzie jest też dusza jako przedmiot targu, ale ani jej ekwiwalent, ani okoliczności zawierania kontraktu nie zostały ujawnione. Niemniej nawet tak skrócona narracja wnosi szereg cennych informacji o sprzedającym, który podejmując decyzję o „zaprzedaniu” duszy, ma świadomość zdrady wobec samego siebie. Oddając duszę pod władanie diabła, nie tylko traci wolność na tym świecie, ale także skazuje się na wieczne męki w piekle, wyrzekając się zbawienia. Kognitywne podstawy treści istotnych dla „zaprzedania duszy" ujawniają przedpojęciowe schematy wyobrażeniowe: SIŁY (poddanie się działaniu mocy nieczystej), wIĘzI (utrata więzi z Bogiem na rzecz związania się ze złym duchem), KONTROLI (utrata kontroli nad swoim losem), PERYFERII (oddalenie się od Boga - centrum mocy), częścI (dezintegracja osobowości, a w konsekwencji utrata życia) oraz schematu sKALI, który wskazuje na ekstremalną wartość minusową (ciało bez duszy staje się martwe, dusza trafia do piekła).

Nie znaczy to jednak, że przyczynowo-skutkowego schematu narracji o handlu duszą nie da się zrekonstruować, gdyż reprodukowalność mitu znalazła wyraz w serii wyrażeń nawiązujących do prototypowego motywu zaprzedania duszy diabłu, które otwierają możliwość uzyskania pełniejszego obrazu zdarzenia. Na jego rekonstrukcję składać się będą zawarte w nich mikronarracje, które dopełnią opis składników scenariusza: aktu zaprzedania duszy, jej ekwiwalentu, ról uczestników zdarzenia - ich intencji, przyczyn i skutków działania. Zastosowanie przedpojęciowych schematów wyobrażeniowych do analizy poszczególnych składników scenariusza pozwoli na ukazanie dominanty semantycznej, będącej filarem konstrukcyjnym danego fragmentu zdarzenia.

Informacje o finalnym akcie transakcji wnoszą frazemy z ekwiwalentem modalnym dla zaprzedać - podpisać / oddać (się) [diabłu], które kładą akcent semantyczny bądź na samo złożenie podpisu, bądź wręcz na akt oddania się (lub kogoś - podległego sprzedawcy) pod władanie diabła, co oznacza pozbawienie się lub kogoś wolności i jest bezpośrednim powieleniem Cyrografu Adama. Schemat sıŁY realizuje się tu jako rezultat przymusu zewnętrznego - ofiara podpisuje, oddaje się pod władanie dyspozytora mocy nadprzyrodzonej, por.:

diabłu podpisać 'zaprzedać, zapisać kogoś diabłu’: poset na fare ku staremu fararovi $i$ i poviada mu [...] ze oćec go d'ablovi potpisał (SGP V: 514);

oddać duszę diabłu, oddać się diabłu (ibid.: 515);

Było tak ne zrobić, ńe prèedać mńe diabłoin (ibid.: 508). 
Natomiast mikronarracje zawarte $\mathrm{w}$ stereotypowych sądach o transakcjach z diabłem wnoszą do scenariusza charakterystykę samych uczestników zdarzenia oraz pełnionych przez nich ról, por.:

Bóg daje szczodremu/šěrèmu, a djåbèt skąpemu / хcëvèmu (ibid.);

D'iobou dycko na iedna kupa vali (tam, gdzie jest dobrobyt, tam jeszcze dodaje) (ibid.: 509);

Djåbeł to je ńerobijåša parobk, bo on za ńeuo robi i (ibid.);

Trzymać się jak diabet soltysa: tšima še ịag diabưu sountisa za grůmacke piȳnze (ibid.: 516);

mieć spótkę $z$ diabłem: to podobno miou spuuke $z$ diabunym ii tyn diabou dostorcou mu pińinzy (ibid.: 515);

zdiabtem dzierżyć: ůn z djoblum źeržy, bo ṕińynzy mo dycki peun no kapsama (ibid.: 516).

Z narracji zawartych w przytoczonych przykładach wynika, że rola inicjatora akcji przypada diabłu, który starannie dobiera sobie partnera kontraktu, opierając się na jego skłonnościach do lenistwa i chęci bogacenia się. Charakterystyka sprzedawcy oparta na jego słabych stronach stawia go w roli pacjensa (uczestnika doświadczającego), podczas gdy diabeł - jako agens - kieruje akcją i realizuje przyczynowo-skutkowy schemat wydarzenia: wybiera ofiarę (chciwą bądź leniwą), oferuje pieniądze lub pomoc w pracy (w zamian za podpisanie cyrografu), a motywowany chciwością/lenistwem kontrahent przyjmuje propozycję, wchodzi w układ z diabłem (godzi się zaprzedać diabłu duszę za pieniądze lub pomoc w pracy). Scenariusz opiera się głównie na schemacie sıŁY, przy czym sprzedający podejmuje działania pod wpływem „przymusu wewnętrznego” (chciwości), a diabeł korzysta z nadprzyrodzonego źródła mocy, stosując wobec ofiary presję w postaci „przymusu zewnętrznego".

Więcej szczegółów wnoszą frazemy, których struktura znaczeniowa wskazuje na konsekwencje konszachtów z diabłem. Mikronarracje pozwalają na rekonstrukcję relacji łączących sprzedającego z kupującym, odsłaniają intencje diabła oraz skutki bratania się z mieszkańcem piekła. Scenę budują głównie schematy wIĘzI (sprzedający, wchodząc w bliskie związki z diabłem, traktuje go jak druha, członka rodziny - brata, kuma, stryjka), sıŁY (szatan wykorzystuje moc nadprzyrodzoną, oczarowuje ofiarę, by nakłonić ją do wejścia w układ, a następnie porwać duszę do piekła), CZ̨̨ść - CA£ość (sprzedający traci duszę, ciało pozbawione duszy umiera), SKALI (negatywnej ocenie podlega prawdziwa, ukryta intencja szatana oraz naiwność sprzedawcy). Kara stanowi ocenę czynu. Frazemy z komponentami piekło/ śmierć pełnią funkcję ostrzeżenia przed skutkami konszachtów z siłą nieczystą, co wskazuje na to, że schemat destrukcji (CZ̨̨ść - CAŁość) pełni tu funkcję dominu- 
jącą, podczas gdy schematy WIĘZI i sKALI dopełniają znaczenie przekazu zawartego w narracji, por.:

diachelskö przëjazń kuńczy sę wiedno szëbienicą (NKPP I: 426);

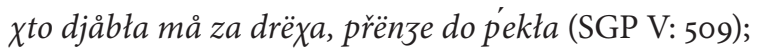

to $z$ djabła je za jedno, dostańe v ṕekle nålepši plac (ibid.);

zrób djåbłu abo djabłovi dobře, a on ce ṕekłem odpłaci (ibid.);

jak mász dziábła strykiem ['stryjaszkiem'], to się leko do piekła dostaniesz (ibid.);

kto fṕekle sunuzí, to musi dịabua fkùmotri víniosć (ibid.).

Natomiast schematy wIĘZI i sıŁY zajmują prymarną pozycję w mikronarracjach obrazujących podległą pozycję sprzedawcy w relacjach z diabłem (oddać się / popaść pod władzę diabła, pracować na rzecz diabła). Schemat pojemnika ukazuje sposób, w jaki „zły” jednoczy się ze swoją ofiarą (sprzedający ma diabła za skórą / za uszami, jest podfutrowany diabłem), podczas gdy schemat sKaLI zawiera ocenę sprzedawcy (zły, dwulicowy) i jego związków z diabłem (konszachtów), por.:

bołem se diabłu oddać [...], to mu djebli wszyćko powiedzieli (ibid.);

(kiegoś) djabła popaść, popaść diabła za rogi 'diabeł kogoś podkusił’ (ibid.: 514);

diabtem narabiać 'mieć konszachty z diabłem' (ibid.)

diabłem być podfutrowanym, diabłem topić ‘być złym człowiekiem' (ibid.);

mieć diabła za skórą / za uszami 'mieć konszachty z diabłem' (ibid.: 515);

rob'ić diabłu na kapelusz 'pracować u kogoś po zachodzie słońca' (ibid.);

składać diabłu na buławę 'być dwulicowym' (ibid.: 516).

Aksjologiczną wartość przedmiotu targu, jakim jest dusza, najlepiej oddają mikronarracje zbudowane na schematach SKALI (PLUs - MINUS) oraz SIEY (jako przymusu wewnętrznego), zawarte w wyrażeniach obrazujących determinację szatana, by zdobyć duszę. Wartość duszy przedstawianej jako przedmiot pożądania diabła stanowi jeden ze sposobów jej waloryzacji, por.:

zawzinty/tapczywy jak djaboł na dusze (SGP VI: 498);

czekac jak diabel na dobra dusze (ibid.);

siedzi jak djabol na grzysznej duszy (ibid.: 499);

siedzieć na grajcarze jak diabeł na duszy 'być bardzo skąpym, strzec swoich pieniędzy' (ibid.); 
stoi jak kat nad grzeszna dusza (ibid.);

strzec jak diabel grzesznej duszy (ibid.);

strzec na (coś), jak diabeł na dusze (ibid.);

trzaść się jak diabeł na dusze 'być bardzo chciwym, pożądliwym, bardzo czegoś pragnąć' (ibid.).

Schemat SKALI PLUS - MINUS zawarty w formułach przysiąg na duszę wskazuje na jej najwyższą waloryzację z perspektywy ludzkiej (biegunowa pozycja na skali PLus). Ekwiwalentem aksjologicznym duszy są tu wartości kardynalne, prawda i zbawienie, por. przysięga, zaklęcie wzmacniające zapewnienie, mówienie prawdy:

na mö́ duśu, ze provde godom! (ibid.: 497);

jako zbawiynio dusy pragne, prawda! (ibid.).

Schematy SKALI oraz SIŁY (jako przymusu wewnętrznego) ukazują też wartość duszy z perspektywy sprzedającego, który skłonny jest zapisać ją diabłu, by zdobyć przedmiot swego pożądania, jakim może być talent, wiedza tajemna bądź ukryte w ziemi skarby. Już same nazwy przedmiotów pożądania - magiczne skrzypce, księgi bacowskie, skarb (ukryty) - zawierają explicite charakterystykę przedmiotu targu, a implicite wskazują na jego nabywcę oraz diabła jako inicjatora kontraktu. Na treść przedstawionych niżej mikronarracji zawartych w nazwach przedmiotów kupna składają się konotacje, które stanowią wspólną dla użytkowników języka wiedzę o ich nadzwyczajnych właściwościach:

- Magiczne skrzypce według ludowych wierzeń nadają muzyce nadzwyczajną moc, która porywa słuchaczy do szaleńczego tańca aż do utraty tchu. Instrument może też sam grać, bez udziału muzykanta. Skrzypcom przypisywano posiadanie duszy, z czym wiązano siłę oddziaływania muzyki na słuchaczy (Piotrowski 2017: 3-5).

- Bacowskie księgi / bacowskie czary / bacowskie pacierze to spisana bądź ustnie przekazana bacy wiedza dotycząca uprawiania czarów. Owe księgi czy przekazy zawierać miały tajne formuły magiczne zwane páciorzami bacowskimi, które miały zabezpieczyć owce, pasterzy i dobytek przed złymi siłami i urokiem (KąśILG I: 166; Rak 2015: 72).

- Ukryte skarby wiązały się z wierzeniami dotyczącymi zakopanych w ziemi kosztowności (złota, pieniędzy, drogich kamieni), których strzegły diabły i ludzkie dusze za złoto kupowały (SSiSL I/3: 176). Przysłowia czart złoto na bagnach suszy; czart złoto na bagnach przepala (NKPP III: 894) wnoszą do mikronarracji informacje o miejscach, na które diabeł wabi poszukiwaczy skarbów, dając im znaki w postaci błędnych ogników. W ten sposób czart wciąga swe ofiary w pułapkę, by zdobyć ich dusze - czart pokaże złoto, a wciagnie w błoto (NKPP I: 354). Opozycja 
błoto - złoto opiera się na schemacie SKALI, który służy ewaluacji samej transakcji z diabłem o duszę. PLUs z wartością złoto przypada w niej duszy, a MINUs zrównuje rezultat targu z błotem.

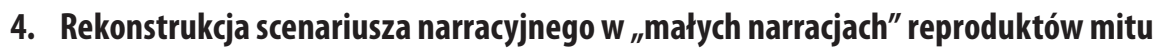 (motywach tekstów folklorystycznych)}

Bardziej rozbudowane formy wypowiedzi, jakimi są motywy tekstów folklorystycznych traktujących o zaprzedawaniu duszy diabłu, wnoszą więcej szczegółów do przyczynowo-skutkowego schematu wydarzenia. Małe narracje zawarte w motywach pozwalają na uzupełnienie brakujących elementów scenariusza - czasu, miejsca, okoliczności, w jakich odbywa się transakcja. Ujawniony zostaje sprzedawca oraz powodujące nim motywy, dla których stawia on przedmiot pożądania ponad duszą.

\subsection{Motyw diabelskiego muzykanta}

Stereotypowym sprzedawcą duszy w zamian za talent / czarodziejskie skrzypce jest ludowy muzykant, por.:

Każdy skrzypek sprzedaje duszę swoją czartu, a ten mu ją zabiera podczas skonania (Muz; Kolberg 1967: 273);

Jednemu skrzypkowi dyabli dali zdolność do muzyki, lecz tylko na pewien czas, poczem miał im dać duszę (Muz; Pawłowicz 1896: 243);

Opowiadają, że przed kilkudziesięciu laty żył w Zalasowej skrzypek, któremu dyabeł dał do muzyki tak wielki talent, że gdy grał, leżąc na łóżku, buty, nad nim na kołku wiszące, poruszały się i obcas trzaskał o obcas (Muz; Pawłowicz 1896: 243).

Konstrukcja sceny opiera się przede wszystkim na schemacie sıŁY w formie przymusu zewnętrznego. Diabeł niespodziewanie zjawia się przed muzykantem (zwykle na weselu lub w karczmie), wręcza mu instrument i każe na nim grać, muzykant ulega mocy, która stopniowo rozszerza zasięg i siłę oddziaływania - moc przechodzi z diabła na grajka, a następnie z muzykanta na instrument (skrzypce, basy same grają), a dalej na przedmioty znajdujące się w pobliżu (buty się same poruszają i trzaskają obcasami), by ostatecznie udzielić się słuchaczom, którzy porwani muzyką ruszają w obłąkańczy taniec kończący się śmiercią z wyczerpania (Piotrowski 2017: 3-5). Drugim filarem konstrukcyjnym sceny jest schemat wIĘZI, jaką diabeł nawiązuje z grajkiem, obdarzając go niebywałym talentem, oraz schemat sıŁy o długotrwałym działaniu, która uzależnia go od muzyki. Grajek podczas muzykowania sam wpada w trans, a oddziałując na innych ludzi, staje się wykonawcą planu diabła, 
który nie tylko jemu odbiera duszę, ale zdobywa też dusze jego słuchaczy, którzy ponieśli śmierć, zatraciwszy się $\mathrm{w}$ tańcu, por.:

Był owczarczyk z Mogilna, który miał flet zaczarowany. Kto jego głos usłyszał, musiał tańcować. Ksiądz nie wierzył pogłosce, poszedł do owczarczyka i kazał sobie zagrać. Chłopiec zagrał, a ksiądz musiał się na śmierć zatańcować (Knoop 1894: 754; Piotrowski 2017: 5)

Jednemu skrzypkowi dyabli dali zdolność do muzyki, lecz tylko na pewien czas, poczem miał im dać duszę (Muz; Pawłowicz 1896: 243).

Śmierć grajka stanowi typowe zamknięcie narracji oparte na schemacie część CA£ość. Porwanie duszy przez diabła w momencie śmierci muzykanta realizuje dalekosiężny diabelski plan dezintegracji, powielając archetypowy wzorzec czerpany z Cyrografu Adama (zawładnięcie duszami całego rodzaju ludzkiego).

Jednakże teksty folkloru dostarczają alternatywnych wzorców zakończeń, w których wiara i religijna postawa grajka uwalnia go od mocy czarta. Grajek udaje się do spowiedzi - traci talent, ale odzyskuje duszę. Finał scenariusza jest semantycznie złożoną konstrukcją z hierarchicznie powiązanych schematów: sıŁY - oddziałującej na muzykanta $\mathrm{w}$ formie wewnętrznego przymusu (wiary i religijnych przekonań, CENTRUM - PERYFERII (zbliżenie do Boga - centrum mocy)), KONTROLI (wyrwanie się spod wpływu diabła) oraz schematu cz̨̨ść - CA£ość (uratowanie duszy). Filarowym elementem konstrukcji jest schemat sıŁy. Obrazowanie działania rozpoczętego pod wpływem przymusu wewnętrznego pociąga za sobą włączanie dalszych schematów, współtworzących finał sceny. Schemat SKALI z waloryzacją PLUS na rzecz uratowania duszy kosztem utraty talentu odgrywa decydującą rolę w aksjologicznej ocenie bohatera i nadaje wydarzeniu pozytywny wydźwięk, por.:

Przed kilkunastu laty znaliśmy człowieka (we wsi Karwowie), o którym powiadano, że dawniej ślicznie grać umiał i gdy tylko wziął w ręce albo powiesił je na ścianie, one mu same grały. Ale przy spowiedzi ksiądz zakazał mu grać. Od tego czasu (mówili), choć weźnie skrzypce do ręki, już nigdy nic nie zagra (Muz; Sadkowski 1903: 683).

Reprodukowalność znajduje wyraz w liczebności wariantów, które dopuszczają zarówno odmienne zakończenia, jak i niestandardowy przebieg wydarzenia. Motywy bajkowe dostarczają licznych przykładów transakcji z diabłem, w których archetypowe role uczestników kontraktu zostają odwrócone. Choć okoliczności i cel nawiązania kontaktu między diabłem a muzykantem są podobne, to w finalnej scenie inicjatywę przejmuje chytry grajek, który nie tylko narzuca warunki kontraktu, ale także udaje mu się przechytrzyć diabła, por.:

[...] muzykant, wracając z wesela, zabłądził w lesie. Skrzypek zagrał na swoim instrumencie, a wtedy stanął przed nim diabeł w postaci $\rightarrow$ pana i zaoferował, że zaprowadzi go do domu w zamian za duszę. Grajek, utargowawszy dodatkowo czapkę pieniędzy, 
zgodził się zawrzeć pakt, jednak - zamiast własnej - oddał czartowi duszę skrzypiec. Czart zorientował się, że padł ofiarą oszustwa, gdy porwana przezeń dusza - jako „smolna” - w chwilę spaliła się w $\rightarrow$ ogniu piekielnym (Skrzyp; Saloni 19o8: 254-255).

\subsection{Motyw czarnoksiężnika - pana Twardowskiego}

W ludowej tradycji utrwaliły się wątki przedstawiające Twardowskiego jako czarnoksiężnika, który wprawdzie zawarł pakt z diabłem i w zamian za wiedzę tajemną podpisał cyrograf na duszę, jednakże dzięki mocy modlitwy wymknął się z pazurów diabła, gdy ten niósł go już do piekła, por.:

[...] w bocheńskim powiecie... lud mieści na księżycu czarownika Twardowskiego.

Szatan miał go tam porzucić, chociaż do piekła miał być porwany. Twardowski bowiem zaczął śpiewać godzinki, a śpiewaniem tem osłabił moc złego ducha. Na księżycu Twardowski pokutować będzie do sądnego dnia (SSiSL I/1: 185);

Jeszcze kiedyś mi mama, matka opowiadała, że Twardowski na księżycu jest, bo pokutuje... (Bartmiński 1989: 115, tamże liczne warianty zapisu).

Porównanie narracji opartych na wątku uwolnienia się z pęt diabła przez grajka i czarnoksiężnika wykazuje wyraźne podobieństwo w konstrukcji scenariuszy. Obaj bohaterowie ulegają czartowskiej mocy i obaj się od niej uwalniają dzięki odwołaniu się do mocy boskiej. Niemniej schemat wyobrażeniowy sıŁY w postaci finalnej konfrontacji sił dobra i zła jest w scenariuszu Twardowskiego dominujący i ukierunkowany na zobrazowanie mocy boskiego miłosierdzia oraz aksjologicznej wartości wiary i pokuty.

\subsection{Wątek bacy czarownika}

Słowo baca jest terminem pasterskim rozpowszechnionym na całym obszarze Karpat, a na Podhalu, Spiszu i Orawie oznacza zwierzchnika juhasów - owczarzy wypasających w okresie wiosenno-jesiennym owce na halach (SKarł I: 32; SGP I: 240-241; ZborSG: 7; KąśSGO I: 16; KąśILG I: 160). Ze względu na najwyższy prestiż, jakim cieszył się ten zawód w społeczności góralskiej, jak też na rolę pasterstwa jako głównego pola działalności górali, wyraz ten został zaliczony przez Macieja Raka do kulturemów podhalańskich - najważniejszego słownictwa oddającego specyfikę tego regionu (Rak 2015: 69-84).

Natomiast postać bacy czarownika jest wytworem wierzeń, które rozwinęły się w narracjach o nadzwyczajnych zdolnościach zawdzięczanych wiedzy danej przez Boga lub diabła, por.: 
Baca to cłek, co wselinijakie cary zná i ón je dochtorym dlá statku i ludzi, i wselinijakom biyde zratuje. Cary to wielgá siyła od Boga daná cłowiekowi. I cłek jom na złe przýbráł, i z djabłym sie złoncył. Ale jak cłowiek kce dobra insymu przýcýnić, to kontrakt spisuje z janiołym, coby go spómóg, i wte djaboł ni má nijakiego przýstympu, i mozno na dobre przýcýnić. Bace znajom wselinijakie przýwileje, takie ku dobrymu i takie ku złymu (BazWP: 78; Rak 2015: 71).

Małe narracje pochodzące $z$ relacji ustnych o słynnych bacach czarownikach pozwalają na odtworzenie aktu przekazywania wiedzy magicznej następcy czarownika z określeniem miejsca, czasu, okoliczności oraz ról uczestników zdarzenia. Młody baca (syn lub uczeń) zostawał mianowany następcą dopiero w momencie śmierci swego poprzednika. W akcie wtajemniczenia umierający baca występuje w roli diabła, a cyrograf zostaje zastąpiony przysięgą zachowania tajemnicy oraz przyjęcia obowiązku „czarowania” do końca życia oraz do przekazania tej wiedzy następcy. Młody baca, przejmując wiedzę tajemną, zaprzedaje duszę diabłu, który występuje w tle sceny ${ }^{6}$, por.:

Baca Wojciech [...] (ok. 1885-1951). Według informatorów pobierał nauki u starszego i doświadczonego czarownika z okolicy Kiczni, inni twierdzą, że praktykował u bacy w Lewoczy, gdzie zaprzedał duszę diabłu.

Będąc w posiadaniu tajemnej wiedzy (prototypowo przekazanej przez ojca lub dziada), czarownik mógł ludziom pomagać (sprowadzać urodzaj, panować nad pogodą, leczyć) lub szkodzić (niszczyć zbiory, powodować wyjałowienie ziemi, sprowadzać choroby na owce i bydło), por.:

Ja n [...] (1880 - ?) [...]. Był bacą, podobnie jak jego ojciec Jan. Obaj cieszyli się sławą czarowników. Leczyli zwierzęta, które zachorowały w wyniku rzucenia carów, pomagali także ludziom;

Ja n [...] (zmarł w 1914). Potrafił skutecznie przepędzać chmury gradowe, powstrzymywać ulewę podczas powodzi, a także przywoływać deszcz w trakcie suszy.

Tomasz [...] (ok. 1831-1913). Baca ten uważany był za jednego z najlepszych czarodziei w okolicy [...]. Skutecznie odczyniał rzucone uroki. Leczył oraz udzielał rad z zakresu medycyny, posługując się czarodziejską księgą, którą wraz z duchem-pomocnikiem przechowywał w dobudowanej do szałasu komórce.

Wątek bacy czarodzieja wnosi nowe możliwości reprodukowania mitycznego motywu Cyrografu Adama. Novum - w stosunku do poprzednich interpretacji polega na wycofaniu się ze sceny transakcji głównego jej inicjatora - diabła. Zajęcie

$6 \mathrm{~W}$ poniższych przykładach podaję materiał zaczerpnięty z portalu https://szlakwoloski.eu/kultu ra-woloska/dziedzictwo-kultury-woloskiej/zaklecia-zamawiania-i-modlitwy-pasterskie (dostęp: 9 VI 2021). 
pozycji w tle zdarzenia wynika $\mathrm{z}$ dalekosiężnej strategii zdobywania dusz przy pomocy pośredników - czarodziejów, którym diabeł udzielił dziedzicznego dostępu do wiedzy tajemnej. Ustanowienie zasady dziedziczenia, połączonego $\mathrm{z}$ obowiązkiem przekazania następcy umiejętności posługiwania się magią, zapewnia diabłu niekończący się dopływ nowych dusz. Samospełniający się szatański plan znajduje odzwierciedlenie w skondensowaniu przebiegu akcji. Początek i koniec zdarzenia zbiegają się w czasie. Zaprzedanie jednej, a odebranie drugiej duszy odbywa się w tym samym momencie, bez bezpośredniego udziału diabła. Natomiast początek ciągu zdarzeń (pierwsze kuszenie) jest już bezpośrednim nawiązaniem do mitu Cyrografu Adama, w którym diabeł sięga po duszę syna pierwszego rodzica - Kaina. Cały scenariusz opiera się na schemacie sıŁY, który dla każdego z bohaterów stanowi inną motywację działania. Dla starego bacy jest to przymus zewnętrzny (przysięga), a dla młodego przymus wewnętrzny (żądza zdobycia magicznej mocy). Dla wszystkich uczestników akcji jest to siła długiego oddziaływania z ambiwalentną waloryzacją. Zdolność uprawiania białej magii wydaje się nie stać w sprzeczności z religijnością ludową (magiczne zaklęcia wypowiadane są często razem ze słowami modlitwy) i jest w kulturze pasterskiej akceptowana, co na sKALI ocen daje pozycję PLUs, podczas gdy stosowanie czarnej magii otrzymuje wartość MINUs.

\section{Powielanie wzorca - przeżywanie mitu}

Dominująca w kulturze tradycyjnej ustna forma przekazu stwarzała sprzyjające warunki do reprodukowalności treści mitycznych, zwłaszcza że wspomagała je narracyjna siła przekazu. Odtwarzanie archetypowej sceny kontaktu pierwszego rodzica ze złym sacrum, w której diabeł podstępem zmusza Adama do zaprzedania mu syna Kaina, stanowi punkt wyjścia do poszukiwań odpowiedzi na pytanie, jakie konsekwencje pociągają za sobą wszelkie relacje z siłą nieczystą. Powielenie mitycznego zdarzenia w postaci mniej lub bardziej rozwiniętych wątków osnutych na Cyrografie Adama odsłania sposoby przeżywania mitu. Przewidywania zagrożeń i ostrzeżenia przed skutkami konszachtów z diabłem wnoszą głównie mikronarracje (paremie, frazemy). Natomiast małe narracje zawarte w motywach bajek, legend oraz opowieści wierzeniowych skupiają się na przeżyciu dramatu ofiary knowań diabła, a niekiedy satysfakcji z powodu udaremnienia szatańskich planów.

Różne warianty motywu Cyrografu Adama i związana z tym wielość interpretacji obecna w wielogatunkowym zbiorze tekstów współtworzą ustrukturyzowany i wieloaspektowy obraz oparty na wzorcowym schemacie narracyjnym mitycznego wydarzenia. Małe narracje i mikronarracje zawarte w motywach badanych tekstów pozwoliły na rekonstrukcję scenariusza zaprzedawania duszy diabłu z uwzględnieniem różnych punktów widzenia, profilowania postaci bohaterów dramatu (gospodarz leń, skąpiec, bogacz, pasterz czarownik) i całej gamy ocen (dobry - zły). Narra- 
cyjne ujęcie sytuuje scenę w szerszym kontekście językowego obrazu przenikania się świata realnego z rzeczywistością nadprzyrodzoną.

\section{Literatura}

BARTMIŃski J., 1989, Relacje o kosmosie. Teksty gwarowe z okolic Biłgoraja, „Etnolingwistyka. Problemy Języka i Kultury" 2, s. 95-149.

BARTMIŃSKI J., 2006, Jęzkowe podstawy obrazu świata, Lublin.

BARTMIŃski J., 2014, Narracyjny aspekt definicji kognitywnej, [w:] D. Filar, D. Piekarczyk (red.), Narracyjność języka i kultury, Lublin, s. 99-115.

Bartmiński J., Niebrzegowska S., 1998, Profilowanie a podmiotowa interpretacji świata, [w:] J. Bartmiński, R. Tokarski (red.), Profilowanie w języku i w tekście, Lublin, s. 211-224.

Bartmiński J., NiebrZeggowska-Bartmińska S., 2004, Dynamika kategorii punktu widzenia w języku, tekście i dyskursie, [w:] J. Bartmiński, S. Niebrzegowska-Bartmińska, R. Nycz (red.), Punkt widzenia w języku i w kulturze, Lublin, s. 321-358.

BAzWP: B. Bazińska, Wierzenia i praktyki magiczne pasterzy w Tatrach, [w:] W. Antoniewicz (oprac.), Pasterstwo Tatr Polskich i Podhala, t. 7: Życie i folklor pasterzy Tatr Polskich i Podhala, Wrocław 1967, s. 65-229.

Campbell J., 1994, Potega mitu. Rozmowy Billa Moyersa z Josephem Campbellem, oprac. B.S. Flowers, Kraków.

Chlebda W., 2010, Frazematyka, [w:] J. Bartmiński (red.), Wspótczesny język polski, wyd. 3, Lublin, s. 335-342.

Chlebda W., 2020, Reprodukowalność, reprodukcja, reprodukty, [w:] idem, J. Tarsa (red.), Frazeologia a reprodukowalność w teorii i w praktyce komunikacyjnej. Problemy - metody analizy - opis, „Intercontinental Dialogue on Phraseology”, t. 6, Białystok, s. 27-50.

Eliade M., 2000, Traktat o historii religii, Warszawa.

Filar D., 2013, Narracyjne aspekty językowego obrazu świata. Interpretacja marzenia we współczesnej polszczyźnie, Lublin.

Johnson M., 1990, The Body in the Mind. The Bodily Basis of Meaning, Imagination, and Reason, Chicago - London.

KąśILG: J Kąś, Ilustrowany leksykon gwary i kultury podhalańskiej, t. I: A-B, Bukowina Tatrzańska - Nowy Sącz - Nowy Targ 2015, t. II: C-Do, Bukowina Tatrzańska - Nowy Sącz - Nowy Targ 2015, t. III: Dó-Gr, Bukowina Tatrzańska - Nowy Targ 2016, t. IV: Gu-Kol, Kraków 2017, t. V: Kot-Mad, Nowy Sącz 2017, t. VI: Maf-Nie, Nowy Sącz 2018, t. VII: Nif-Pap, Nowy Sącz 2018, t. VIII: Par-Pou, Nowy Sącz 2018, t. IX: Pow-Sce, Nowy Sącz 2019, t. X: Sch-Sró, Nowy Sącz 2019, t. XI: Śry-Wych, Nowy Sącz 2019, t. XII: Wyci$-\dot{Z}$, Nowy Sącz 2019.

KąśSGO: J. Kąś, Słownik gwary orawskiej, Kraków 2003; wyd. 2 popr. i poszerz., t. 1-2, Kraków 2011.

Knoop O., 1894, Podania i opowiadania $z$ Wielkiego Księstwa Poznańskiego, „Wisła” VIII, Z. 4, s. 719-774.

Kolberg O., 1967, Dzieła wszystkie, t. 48: Tarnowskie-Rzeszowskie, z rękopisów oprac. J. Burszta, B. Linette, Kraków-Warszawa.

Krzeszowski T., 1994, Parametr aksjologiczny w przedpojęciowych schematach wyobrażeniowych, „Etnolingwistyka. Problemy Języka i Kultury” 6, s. 29-51. 
Krzeszowski T., 1999, Aksjologiczne aspekty semantyki językowej, Toruń.

LibURA A., 2000, Wyobraźnia w języku. Leksykalne korelaty schematów wyobrażeniowych CENTRUM-PERYFERIE i SIEY, Wrocław.

Lurker M., 1994, Przesłanie symboli w mitach, kulturach i religiach, Kraków.

MasıowsKa E., 2014, Narracyjność symbolu. Ludowe narracje budowane na bazie lunarnej symboliki przejścia, [w:] D. Filar, D. Piekarczyk (red.), Narracyjność języka i kultury, Lublin, s. 239-249.

Muz: O. Zadurska, Muzykant, [w:] V. Wróblewska (red.), Słownik polskiej bajki ludowej, [on-line:] http://bajka.umk.pl/slownik/lista-hasel/haslo/?id=120 (dostęp: 9 VI 2021).

Niebrzegowska-Bartmińska S., 2020, Definiowanie i profilowanie pojęć w (etno)lingwistyce, Lublin.

NKPP: J. Krzyżanowski (red.), Nowa księga przysłów i wyrażeń przysłowiowych polskich, t. 1-4, Warszawa 1969-1978.

PAwŁowicz B., 1896, Kilka rysów z życia ludu w Zalasowej, „Materiały Antropologiczno-Archeologiczne i Etnograficzne" 1, s. 229-265.

Piotrowski R., 2017, Diabelscy muzykanci i tancerze w materiałach folklorystycznych $i$ etnograficznych, „Literatura Ludowa” 3, s. 3-12.

RAK M., 2015, Kulturemy podhalańskie, „Biblioteka LingVariów”, t. 19, Kraków, https://doi. org/10.12797/9788376386027.

SAdKowski I., 1903, Szlachta drobna w powiatach płońskim i płockim, „Wisła” XVII, z. 6, s. $669-687$.

SAlOni A., 1908, Lud rzeszowski. Materiały etnograficzne, „Materiały Antropologiczno-Archeologiczne i Etnograficzne" 10, s. 50-344.

SGP: Słownik gwar polskich, red. M. Karaś (Źródła, t. 1), J. Reichan (t. 2-9, z. 2), S. Urbańczyk (t. 2-5), J. Okoniowa (t. 6-9, z. 2), B. Grabka (t. 7-9, z. 2), R. Kucharzyk (t. 9, z. 2-t. 10, z. 2), t. 1-3: Wrocław - Warszawa - Kraków 1977-1991, t. 4-10: Kraków 1992-2019.

SKARŁ: J. Karłowicz, Słownik gwar polskich, t. I-VI (t. IV-VI do druku przygot. J. Łoś), Kraków 1900-1911.

Skrzyp: O. Zadurska, Skrzypce, [w:] V. Wróblewska (red.), Słownik polskiej bajki ludowej, [on-line:] http://bajka.umk.pl/slownik/lista-hasel/haslo/?id=159 (dostęp: 9 VI 2011).

SSISL: J. Bartmiński, S. Niebrzegowska-Bartmińska (red.), Słownik stereotypów i symboli ludowych, t. I: Kosmos, z. 1: Niebo, światła niebieskie, ogień, kamienie, Lublin 1996, z. 2: Ziemia, woda, podziemie, Lublin 1999, z. 3: Meteorologia, Lublin 2012, z. 4: Świat, światło, metale, Lublin 2012, t. II: Rośliny, z. 1: Zboża, Lublin 2017, z. 2: Warzywa, przyprawy, rośliny przemysłowe, Lublin 2018, z. 3: Kwiaty, Lublin 2019, z. 4: Zioła, Lublin 2019, z. 5: Rośliny, drzewa owocowe i iglaste, Lublin 2020.

Szyjewski A., 2008, Etnologia religii, Kraków.

ToKArski R., 1988, Konotacja jako składnik treści słowa, [w:] J. Bartmiński (red.), Konotacja, Lublin, s. 35-53.

ToKARski R., 1993, Słownictwo jako interpretacja świata, [w:] J. Bartmiński (red.), Encyklopedia kultury polskiej XX wieku, t. 2: Współczesny język polski, Wrocław, s. 335-362.

ToKARSKi R., 2001, Typy racjonalności w językowym obrazie świata, [w:] A. Pajdzińska, R. Tokarski (red.), Semantyka tekstu artystycznego, Lublin, s. 231-245.

TokARski R., 2014, Semantyka, onomazjologia i narracje o świecie, [w:] D. Filar, D. Piekarczyk (red.), Narracyjność języka i kultury, Lublin, s. 117-128.

Tоміскі R., 1976, Słowiański mit kosmogoniczny, „Etnografia Polska” XX, z. 1, s. 47-99. 
Tоміскі R., 1980, Ludowe mity o stworzeniu człowieka. Z badań nad synkretyzmem mitologicznym w Europie Wschodniej i Południowej oraz w Azji Pótnocnej, „Etnografia Polska” XXIV, z. 2, s. 49-119.

ZвоRSG: J. Zborowski, Słownik gwary Zakopanego i okolic, oprac. i uzup. z materiałów Aut. przez Zespół Instytutu Języka Polskiego Polskiej Akademii Nauk pod kier. J. Okoniowej, Zakopane - Kraków 2009.

ZowCZAк M., 2000, Biblia ludowa. Interpretacje wątków biblijnych w kulturze ludowej, Wrocław.

\section{Selling One's Soul to the Devil - Reproducibility of the Mythical Motif in Phrasematics of the Polish Colloquial Language in the Context of Traditional Culture} Abstract

The author of the article discussed reproducibility of the mythical motif of "Adam's pact with the devil" in Polish traditional culture and in dialectal and colloquial phrasematics. The adoption of the concept of "language narrativeness" in the description of a small piece of reality such as the act of selling one's soul to the devil, makes it possible to present this piece in a form of a structured image within the frames of a great narrative about the world (based on the Christian belief concerning the soul) which contains small narratives (referring to myths and folk demonology included in stereotypical text motifs) and micro-narratives that are hidden in lexis and broadly understood phrasematics and that reflect a whole range of interpretations and evaluations related to a person's pact with a demonic being. 